\title{
Prevention Methods of Violence against Women and Girls as Shared Efforts by Governments and NGOs
}

\author{
Rossen Petkov \\ City University of New York, Lehman College, USA \\ E-mail: rosspetkov@hotmail.com \\ Atanaska Mindevska \\ City University of New York, Brooklyn College, USA \\ E-mail: mindevska@yahoo.com
}

Received: November 2, 2011

Accepted: January 10, $2012 \quad$ Published: June 1, 2012

doi:10.5539/res.v4n2p33

URL: http://dx.doi.org/10.5539/res.v4n2p33

\begin{abstract}
Violence against women and girl is a widespread problem of human rights and we need to revisit the current prevention programs to ensure proper resolution. Even though, we live in an advance society, violence continues to be an on-goinginternational problem. In this paper, we analyse violence against women and girls in today's society and its effects. We show that violence varies from physical altercation to mental abuse. In addition, we analyse established definitions for violence against women and their international recognition. To supplement this discussion, we would present various political movements by the international community to prevent violence against women. However, as a thesis, we believe that additional political actions are necessary to further prevent and/or reduce these violent acts from occurring in the first place. We think that minimizing or reducing violence against women is a complex process that requires shared undertakings by various parties such as governments, private NGOs, and the individual participation. These devotions would ensure that a proper solution is reached to the undergoing problem. That is, our paper analyses ways to reduce violence against women and girls. We would add recommendations to the existing prevention programs and we would try to make them more effective,via our theoretical proposals, in dealing with the violence against women and girls.
\end{abstract}

Keywords: Violence, Women, Prevention methods

\section{Introduction}

Even though, we live in an advance society, violence against women and girls continues to be an on-goinginternational problem of human rights. In a recently published report by the UN Commission on the Status of Women (2000), the researchers have found that "globally, at least one in three women and girls is beaten or sexually abused in her lifetime". In a "recent survey by the Kenyan Women Rights Awareness Program revealed that $70 \%$ of those interviewed said they knew neighbourswho beat their wives. Nearly $60 \%$ said women were to blame for the beatings. Just $51 \%$ said the men should be punished" (New York Times, 1997). This is clearly unacceptable observation or at least it provides a basis that more needs to be done on this topic. We think that it is essential to revisit some of the current prevention programs to ensure proper resolution.

There are various definitions of violence against women and girls. Many resources define "violence" as: the use of force by people and/or governments to others contrary to their wishes/beliefs to achieve their political and/or economical goals (Britannica, 2000). Violence against women and girls is an act of "violence" targeted specifically at women and girls. For the purposes of this paper, we would use the definition by the Declaration on the Elimination of Violence against Women. In this declaration, the violence against women is defined as "any act of gender based violence that results in, or is likely to result in, physical, sexual or psychological harm or suffering to women, including threats of such acts, coercion or arbitrary deprivation of liberty, whether occurring in public or in private life" (Declaration on the Elimination of Violence against Women, 1993). We believe that this definition properly captures the reality of the violence against women and girls. It includes not only the physical and sexual act but also psychological harm against women. That is, it covers a broad spectrum. 
The premise for violence against women and girls originates with the initiative to change the women's perceptions due to their actions or beliefs. That is, violence causes the perpetrator to force the affected women and girls to suffer for their beliefs. It is often believed that violence is used as a tool of manipulation and to force others to accept someone else's ideals. Violence against women and girls takes place in all layers of society and it has no boundaries. This violence could be in various forms such as sexual, psychological and it can have an emotional impact on the victim (Garcia-Moreno et al., 2006). In a recent UNICEF report (2002), "an estimated one million children, mostly girls, enter the sex trade each year". In 2002, this report became a Convention on the Rights of the Child on the sale of children, child prostitution and child pornography. This convention provides some protection for women and girls, but unfortunately violence still exists. In an ideal world, violence should never be justified. People (men and women) are born different as they have their own morals, ideal. These differences should be embraced rather diminished. This ideal society would be much stronger as the differences would help towards its development. Different people, think differently, therefore, the more diverse society we have present, the more developed it would become in the future. However, we do not live in this ideal society and many women and girls are subject to violent acts.

In this paper, we argue that government's intervention and efforts towards reduction of violence is a political act. Therefore, the inability for the governments to fully eliminate and/or minimize violence could also be considered political act. Based on this logic, we argue that such inability for prevention is unfair and unjustifiable. We look at the international recognition of these violence acts and the established political prevention programs. We specifically concentrate on the welfare and education. That is, we show that people subjected to violence as a political act (in its many forms) have a great impact on their future welfare and education. As a thesis, we believe that additional political actions are necessary to further prevent and/or reduce these violent acts from occurring in the first place, in order to minimize the negative effects on welfare and education. We think that minimizing or reducing violence against women is a complex process that requires shared undertakings by various parties such as governments, private NGOs, and the individual participation. These devotions would ensure that a proper solution is reached to the undergoing problem. That is, our paper analyses ways to reduce violence against women and girls. We add recommendations to the existing prevention programs and we would try to make them more effective via our theoretical proposals, in dealing with the violence against women and girls.

\section{Theoretical Underpinnings}

For the purposes of this paper, we argue that government's intervention and efforts towards reduction of violence is a political act. This assumption is generally true as any government action towards adjustment of the social order is considered a political act. As a country readjusts its policies, it establishes rules and regulations, which help shape its political reforms. These reforms are considers political acts in their nature. Therefore, the opposite, that is, the inability for the governments to establish these rules and regulations (when necessary) is also considered a political act of inability. In our case, this act deals with the premise to eliminate and/or minimizing violence against women and girls. However, the issue is not whether a political act or actions need to be present. Rather, we have to analyse the necessity of governments to respond when necessary to adjust the social order and therefore improve the life of its citizens. Clearly on the topic of violence, we would show that the act of violence is unjustifiable. Therefore, any inaction by government to properly reduce it would be considered an unfair and unjustifiable act. Specifically for this paper, we would concentrate of welfare and education. We would argue that people subjected to violence as a political act (in its many forms) have a great impact on their future welfare and education. However, in order to have such a discussion, we need to base our paper on few assumptions/underpinnings, which would be discussed in the following paragraphs. As we note, there are many international programs that exist to prevent and mitigate violence against women. However, these programs are no sufficient to eliminate violence from occurring in the first place. We believe that we need to supplement these acts with additional recommendations to further achieve our objectives.

For the purposes of this paper, wetake the liberal view for reduction / prevention of violence against women and girls. That is, we believe that intergovernmental action is necessary to achieve equal opportunity for men and women. This would result in equality and therefore, proper justice for perpetrators of violence. We believe that the government has a duty to its citizens to help and protect their civil liberties, human and individual rights. That is, we need prevention programs that could guarantee that no one is in need or unprotected when it comes to violence against women and girls. As a result, we argue that shared efforts from various parties, in order to achieve prevention/reduction of violence against women and girls. We understand that there are other possible views for prevention of violence. However, in this paper we take the liberal view, as we believe that it could properly capture the necessity for governmental action to achieve equal opportunity and as a result reduction of violence.

The theoretical underpinnings for this paper are based on following assumptions: 
- Violence against women and girls exists

- There are consequences of violence against women and girls (specially on their future welfare and education)

- There are existing programs to prevent violence against women and girls

- Violence against women and girls is unjustified

In the following sub-sections (2.1-2.4), we discuss each assumption in a greater detail and document its importance. We believe that these assumptions are essential to supplement our thesis that additional political actions are necessary to prevent and/or reduce violent acts from occurring. As previously discussed, we think that minimizing or reducingviolence against women would require shared endorsedefforts from various parties. These devotions would ensure that a proper solution is reached to the undergoing problem.

\subsection{Violence against women and girls exists}

The problem of violence against women has always existed. Most often the violence occurs in families, where it is perpetrated by the husband against the wife. The forms of family violence are different: assaulting, hitting, kicking, threats, verbal abuse, economical abuse, emotional abuse expressed in the creation of psychological discomfort humiliating the woman, threatening her with physical violence, threatening to take her children, to take her home, to humiliate her in the public by slander, etc (Karmen, 2007). In most cases, the woman is deprived of access to money. Sexual harassment is also a form of violence. All of these and other forms of violence are tools that the abuser uses to demonstrate superiority. The most common manifestation of domestic violence occurs after intake of alcohol. In the community, violence is believed to be more common in less-educated families, but research shows that violence occurs in all strata of society (Baker and Ricardo, 2007). Although there is no accurate statistics covering the cases, the police believe that one in every four women is subjected to physical or mental abuse (New York Times, 1997). Many women do not share with anyone that they are victims of domestic violence. This problem is considered "taboo" and something shameful in our society. "The victim is ashamed to be a victim of violence" - it sounds absurd, but it is a fact. It is considered more appropriate not to discuss the problem with anyone else but with the closest and trusted people, such as friends or parents, who give the victim sympathy and nothing else. It turns out that the victim, unwittingly, conceals her oppressor and the violence continues. Some victims say that they get used to it and it becomes a way of life (Karmen, 2007). This is complete absurdity, because if someone is so strong physically and mentally as to be able to become accustomed to violence and accept it, then they have a poor quality of life based on suffering and painful patience, which is not correct as no one deserves such a life.

\subsection{Consequences of violence against women and girls}

We believe that there are direct and indirect consequences of violent acts on the women and girls. These consequences are usually as the result of fear of violence and the intimidation. This keeps the woman subjected, impedes her free movement, and restricts her access to material goods and many basic services. The cultural traditions in our society justify this violence, and often the victims of violence who have terminated their relationship with a violent husband or boyfriend are neither integrated into society nor understood. In families where the husband (boyfriend) beats the woman, usually the child also suffers from physical and mental abuse (Baker and Jaffe, 2007). Thus the child's rights are also violated. Consequently, the child can copy this type of family relations and bring it in his interpersonal relationships in his family later on.

The victims of domestic violence become psychologically linked in a special tyrannical way with the oppressor that deletes their personality (Kaukinen, 2004). The domestic oppressor has a strong comprehensive power over his victim, just because of the fact that he resorts to violence from the position of a protector and guardian (Kaukinen, 2004). This allows him to confuse the concepts of good and evil of the person who is under his power. The victim deals with this maddening situation, considering that she has something bad within herself and therefore deserves such a degrading treatment. The psychological defense mechanisms ensure the survival of the victims of domestic violence, but the defeat of the mental apparatus makes the character and the personality especially problematic (Kaukinen, 2004). The psychiatric problems of these people are very serious and difficult to overcome. Their relations with other individuals, groups and teams are a series of failed attempts to have intimacy free of humiliation, understanding free of subservience or coercion (Kaukinen, 2004). The end result of the violence is that the victim has mutilated, incomplete internal security. The victims of violence consider the world a more hostile and uncertain place than it is for the few lucky immune to this fate (Kaukinen, 2004).

As we have mentioned previously in our paper, the act of violence among women and girls has a major effect on the mental, physical, emotional, financial and spiritual state of the victimized. In the case of violence among women and girls, there is unwillingness towards education and reluctance to start and / or return $t$ old jobs. This 
assumption is based on the fear that they feel that no one would help them and again they could become victims. This attitude and way of thinking would have an impact on the victims and its family. As we mentioned, violence on women and girls has a negative impact on their work. Abused women usually have difficulties finding job because they are stressed out, experience fear and have cannot take leadership initiatives. These results in production of less net income and therefore, these women have difficulties providing the necessities for their families. To reduce these risks many governments adopt different social welfare programs and promote education because it is the foundation for economic empowerment among people and countries. However, these introduced government programs (welfare) are costly and inefficient. This cause inappropriate distribution of funds and develops further inequality. As abuse women have difficulties providing for their families, they also cannot fund their education. This further puts them in a disadvantage. As this cycle occurs, women subjected to violence cannot escape and improve their way of life.

\subsection{Existing programs to prevent violence against women and girls}

There are many international programs that exist to prevent and mitigate violence against women. For the purposes of this paper, we would focus specifically on the Violence Against Women Act (1994) and the Family Violence Prevention and Services Act (1984). We believe that these two acts properly capture the issues at hand and they have proper premises. However, these programs are no sufficient to eliminate violence from occurring in the first place. This is not difficult to prove as there are statistics that violence has not been reduced dramatically over the years. Therefore, we believe that we need to supplement these acts with additional recommendations to further achieve our objectives.

\subsection{Justification for violence against women and girls}

For the purposes of this paper, we assume that violence against women and girls in never justified. As per its definition, "violence" is an act against another, causing that person to change or to be affected due to his/her actions or beliefs. That is, violence causes the perpetrator to force the affected party to suffer for their beliefs and ideals. In an ideal world, violence should never be justified. People are born different as they have their own morals and ideals. Differences between men and women should be embraced rather than diminished. This ideal society would be much stronger as its differences would help towards its development. Different people, think differently, therefore, the more diverse society we have present, the more developed it would become in the future. For the purposes of this paper, in order for our arguments to follow, we assume that violence against women and girls is never justified.

\section{Literature Review on International Instruments on Prevention of Violence against Women and Girls}

Violence is part of the major social "mechanisms, by which women are forced to occupy a subordinate position in society and the family in comparison to men" (Declaration on the Elimination of Violence Against Women, 1993). Unfortunately, violence is present in all layers of the societies and there is no proper immunization to mitigate its effects. Any woman who has been subjected to domestic violence, experiences emotionally the act itself (Kaukinen, 2004). She shuts up in herself and experiences the violence all alone. Consequently, she begins to feel disregarded, humiliated, her internal emotional balance is violated because every person was born to be happy. Hence it negatively affects her status in the family and her closest surroundings. Her emotional state has a negative impact on her ability to work and on her assertion (self-confidence). The inability for the governments to establish these rules and regulations to minimize some of these effects is also considered a political act of inability.

Violence against women as a political act is a display of historically formed relations of negative images of discrimination of women. Unfortunately, such behavior is over allowed and there is not proper punishment. There could be cases of disregard and mental of women or girls and it is mostly unannounced and unrevealed (Karmen, 2007). There might be cases that it could be revealed, but it usually appears to be ineffectivetive to defend the wounded due to the lack of laws condemning violence against women (Karmen, 2007).

The causes of violence against women in the family are many and varied: from economic problems, unemployment, poor living conditions, personal characteristics of the abuser ("selfishness", "stubborn" or "bad character") (Stokes, 2002), to violated relationships within the couple. Another major factor for violence against women involves gender differences. In terms of physical strength, women are disadvantaged compared to men. Demonstration of force is an essential requisite of male behavior. Women are physically weaker than men (Karmen, 2007). But worse is the difference in mental attitude. Traditionally, the little boy in the community is encouraged to build up muscles, whereas the little girl is forced to appreciate the delicate skin, slim body and be obedient and gentle (i.e. passive). 


\subsection{Premise for international recognition - from political development's perspective}

As we have stated in our theoretical underpinning, government's intervention and efforts towards reduction of violence is a political act. The problem of violence against women is not new; its roots are very deep. In the past, women were bought and sold as a commodity; there were even places where newborn female babies were buried alive in the ground (Thun, 2002). Women were not considered equal to men, but inferior. Today we all know that women are as important as men, they are not at a lower position than men.

That is, men are no better than women; women are not better than men. In other words, the position of women is and should be equivalent to the position of men. Women are and should be full and equal partners of men. The human nature of women is neither inferior nor different from that of men. Women are important for the continuation of life to the same extent as men are important. Few could argue that men and women have the same or at least equal privileges and responsibilities. It is important that we use this premise and that we do not distinguish between men and women solely based on their physical attributes and characteristics (Karmen, 2007). The fact that men are stronger physically does not make them more important or superior to women. This quality does not entitle men to the role of the oppressor, on the contrary, this quality carries embedded wisdom that it was given to men to protect and preserve the family, to create a feeling of comfort and security, not to abuse and create terror in it.

In the following paragraphs / subsections, we would present the various political movements by the international community to prevent violence against women. We would present the prevention methods that have been established by the UN, WHO, World Bank, EU and the U.S. Congress.It is critical to note here that these reduction mechanisms (for violence) are political acts in their nature. It is important to define that and analyze their shortages. This would provide us with information regarding their limitations. This would serve our purpose that the inability to further reduce violence is a political act that is unjustifiable in its nature.

\subsection{United Nations Recognition}

In 1993, Violence against women and girls was declared to be a violation of human rights. The same year, the United Nations (UN) General Assembly signed a Declaration on the Elimination of Violence Against Women. In that Declaration a general definition of violence was adopted and it states (1993):

Article 1:

Violence against women shall be understood to encompass, but not be limited to, the following:

(a) Physical, sexual and psychological violence occurring in the family, including battering, sexual abuse of female children in the household, dowry-related violence, marital rape, female genital mutilation and other traditional practices harmful to women, non-spousal violence and violence related to exploitation;

(b) Physical, sexual and psychological violence occurring within the general community, including rape, sexual abuse, sexual harassment and intimidation at work, in educational institutions and elsewhere, trafficking in women and forced prostitution;

(c) Physical, sexual and psychological violence perpetrated or condoned by the State, wherever it occurs.

During the World Conference on Human Rights in Vienna, women's NGOs from all over the world brought to the attention that violence against women and girls is formal acknowledgement of violence against women as human rights. Based on that in the Vienna Declaration and Program of Action adopted a new article - article 18, which states (1993):

The human rights of women and of the girl-child are an inalienable, integral and indivisible part of universal human rights. The full and equal participation of women in political, civil, economic, social and cultural life, at the national, regional and international levels, and the eradication of all forms of discrimination on grounds of sex are priority objectives of the international community. Gender-based violence and all forms of sexual harassment and exploitation, including those resulting from cultural prejudice and international trafficking, are incompatible with the dignity and worth of the human person, and must be eliminated.

After the adoption of Article 18 Cairo Conference on Population and Development (1994), the World Conference on Women in Beijing (1995) and many World-Summits and organizations all over the world reaffirmed their position on this definition. All of those organizations strongly support the idea that the rights of women and girls are an important part of the universal human rights frame structure. "In addition to the International Bill of Rights and the core human rights treaties, there are many other universal instruments such as declarations, principles, guidelines, standard rules and recommendations ect. Some of those legal instruments have no binding legal effect, but there are enforced because they simply provide practical guidance to States" (Office of UN High Commission on Human Rights, 2007). 
"The first legally binding international document prohibiting discrimination against women and forcing governments to take steps in favor of equality for women and men is the Convention on the Elimination of All Forms of Discrimination Against Women" (CEDAW, 1979). This conversion addresses the "rights of women in politics, health care, education, law, property, marriage and family relations" (CEDAW, 1979). There many countries that have ratified this convention.(CEDAW, 1979).

\subsection{United Nation Trust Fund}

In the 2006, United Nations established a fund called the UN Trust Fund in Support of Actions to Eliminate Violence against Women. The resolution states (UN GA Resolution, 1996):

Reiterates its appreciation for the advocacy initiatives of the United Nations Development Fund for Women, including its contribution to and participation in the follow-up to the Vienna Declaration and Programme of Action, in particular with respect to efforts to combat violence against women, commends the Fund for its support of catalytic and innovative projects that strengthen the national capacity to improve the situation of women, and takes note with appreciation of the Platform for Action which affirmed that the Fund had the mandate to increase options and opportunities for wome econom and social development in developing countries by providing technical and financial assistance to incorporate the women's dimension into development at all levels and that it should review and strengthen, as appropriate, its work programme in the light of the Platform for Action, focusing on women's political and economic empowerment;

This UN Trust Fund works with partners across the world to "secure much-needed services for women and girls affected by violence” (UN Trust Fund, 2011). „Through its partners, the Fund also invests in long-term solutions for a world free of violence" (UN Trust Fund, 2011).

\subsection{United States Congress Recognition}

There have been few laws that deal with the issue of violence against women in the United States, such as: Violence Against Women Act (1994) and the Family Violence Prevention and Services Act (1984). The OWH (2011) provides an analysis of these two acts their effect on prevention of violence against women and girls as follows:

\section{A. The Violence Against Women Act}

The Violence Against Women Act (VAWA) was the first major law to help government agencies and victim advocates work together to fight domestic violence, sexual assault, and other types of violence against women. It created new punishments for certain crimes and started programs to prevent violence and help victims. Over the years, the law has been expanded to provide more programs and services.

\section{B. The Family Violence Prevention and Services Act}

The Family Violence Prevention and Services Act (FVPSA) provide the main federal funding to help victims of domestic violence and their dependents (such as children). Programs funded through FVPSA provide shelter and related help. They also offer violence prevention activities and try to improve how service agencies work together in communities.

We believe that "Violence Against Women" and "Family Violence Prevention and Services" acts properly capture the issues at hand and they have proper premises. However, we believe that we need to supplement these acts with additional recommendations to further achieve our objectives. In this subsection, we provide a brief description of these agencies. This is limited with the scope of identifying limitations of the above states prevention acts. We note that these acts should be used as a basic to promote further rules towards reduction of violence against women and girls. We think that minimizing or reducing violence against women is a complex process that requires shared undertakings by various parties such as governments, private NGOs, and the individual participation. These devotions would ensure that a proper solution is reached to the undergoing problem.

\subsection{World Health Organization Recognition}

This organization is under the direct supervision by the United Nations on health and violence issues. "It is responsible for providing leadership on global health matters, shaping the health research agenda, setting norms and standards, articulating evidence-based policy options, providing technical support to countries and monitoring and assessing health trends" (World Health Organization, 2011). World health organization (WHO) response to violence against women is as follows(World Health Organization, 2011):

- building the evidence base on the scope and types of intimate partner and sexual violence in different settings and supporting countries' efforts to document and measure this violence. This is central to understanding the magnitude and nature of the problem at a global level; 
- developing technical guidance for evidence-based intimate partner and sexual violence prevention and for strengthening the health sector responses to such violence;

- disseminating information and supporting national efforts to advance women's rights and the prevention of and response to intimate partner and sexual violence against women; and

- collaborating with international agencies and organizations to reduce/eliminate intimate partner and sexual violence globally.

As we can see from the above list of possible responses by the WHO, there are few mechanism under which the WHO could be more effective towards reduction of violence. However, as with any created mechanisms, these have to be properly followed and executed in order to ensure proper results are achieved towards the main goal of eliminating violence against women and girls. Unfortunately, this is a very complex problem and it would entail the collaboration of many international parties. However, the work of the WHO is a positive step toward the proper solution.

\subsection{World Bank Recognition}

The World Bank is a "vital source of financial and technical assistance to developing countries around the world" (World Bank, 2011). The mission is to "fight poverty with passion and professionalism for lasting results and to help people help themselves and their environment by providing resources, sharing knowledge, building capacity and forging partnerships in the public and individualss" (World Bank, 2011). World Bank also publishes reports on important international issues. In recent report date from 1994, World Bank recognized violence against women. They note that "gender-based violence, including rape, domestic violence, mutilation, murder and sexual abuse is a profound health problem for women across the globe" (Heise et al., 1994). As a suggestion towards resolutions, World Bank(2011)notes:

By taking violence against women seriously, the World Bank can help encourage governments, other lenders, and the world community to do likewise. As a financial and policymaking institution with considerable leverage, the Bank could lend visibility and legitimacy to the issue by incorporating violence into its policy-oriented sector work on poverty, health education, and women in development and by supporting projects addressing violence against women. The Bank can to take action in combating violence, pushing legal reform, and working with victim.

Much of the necessary preventive action will require persist and extensive work through the Bank's sectorial divisions, and a commitment to community organizations, public education, and women's empowerment. In the short run some of the most effective action can be taken by health and family planning agencies and providers.

From the above, we observe recognition of the violence against women from an economic perspective as well. The involvement of the World Bank in the resolution of violence would be a critical one and it would involve further economic and political reforms to improve the economic standard of living and the importance of economic independence of women. Once that these objectives are achieved, we could argue that could see permanent reduction of violence against women and girls.

\subsection{Council of Europe - EU instrument}

The Council of Europe "recognizes equality between women and men as a fundamental human right" (Equality Between Women and Men, 2011). (Council of Europe: Gender Equality, 2011). Article 14 of the European Convention of Human Rights declares that, "the enjoyment of the rights and freedoms shall be secured without discrimination on any ground such as sex, race, colour, language religion political or other opinion..." (Human Right Act, 1998). (Council of Europe: Gender Equality, 2011). As the Council of Europe have discussed in their reports (Council of Europe: Stop Domestic Violence Against Women, 2011), (Council of Europe: Gender Equality, 2011):

This article provides the basis for extensive action for the organisation. The responsible body is the Steering Committee for Equality, between Women and Men (CDEG), which carries out analyses, studies and evaluations, defines strategies and political measures and, where necessary, decides on appropriate legal instruments.

Through awareness raising efforts and campaign such as the 'Stop Domestic Violence Against Women' campaign, the Council of Europe actively addresses gender-based violence. The Council's programme 'Building Europe for and with Children' targets various forms of child sexual abuse: incest, pornography, prostitution, trafficking in human beings and peer sexual assault.

That is, there has been recognition of the violence against women and girls at the EU level. This is critical 
because in order to solve the problem or at least reduce the impact of the effects of violence, there needs to be international recognition of the issue. Once there such recognition, a proper solution could be followed.

\section{Case Analysis for Political Development of New Prevention Programs}

Any action or behavior directed against another person or one's own personality, which causes physical, mental and emotional suffering, can be referred to as violence. By its social nature violence is an anti-human act. It is a kind of crime and violates the dignity and interests of individuals. Violence is one of the possible outcomes of aggressive behavior. Similarly to it, it has many varieties and forms of expression. Violence is manifested in different ways, depending on who the perpetrators and the victims are, and their relations. We have argued that any inaction by a government to properly eliminate and reduce violence, when it is within its powers, would also be considered a political act. This political act of inability is unjustifiable and there not proper.

Statistics have shown that between " $12 \%$ and $15 \%$ of women in Europe face violence at their homes daily"(Council of Europe, 2006). To reflect some of these starling statistics, the Council of Europe (Europe's leading human rights organization) has launched a campaign to its member-states in order to provide support for the victims and to encourage a new attitude in society. This is to ensure that violence against women at home will never be tolerated in the future. Everyone has a particular role. Violence against women, including domestic violence, is a consequence of the imbalance in the power relations of society. It is a violation of human rights and a fundamental impediment to overcoming inequality between women and men. Despite the positive development in legislation, policies and practices, violence still exists in each of the member states of the Council of Europe at all levels of society. (Council of Europe, Declaration: Making gender equality a reality, 2009)

There are interventions that have been currently established to prevent violence against women. We analyzed some of these in our Literature Review Section. However, their effectiveness is yet to be proven. Many researchers believe that we should be more interested not in the detection but in the prevention. That is, to stop violence from occurring in the first place. WHO (2011) shares some of these ideas and further notes that prevention is the key to achievement of further reduction in violence against women. Per the WHO fact sheets (2011), "evidence is emerging for the effectiveness of several other primary prevention strategies: those that combine microfinance with gender equality training; that promote communication and relationship skills within communities; that reduce access to, and the harmful use of alcohol; and that change cultural gender norms". In their suggestion, WHO (2011) believes that in order "to achieve lasting change, it is important to enact legislation and develop policies that protect women; address discrimination against women and promote gender equality; and help to move the culture away from violence."

Preventing and reducing violence would be addressed in this section. We would provide list issues that we think are still present and that adversely affect the prevention of violence. We would provide objective solutions for these issues. We believe that we need to have the shared endorsed efforts from various parties, in order to achieve the objective of reduction of violence against women and girls. Theseshared efforts would provide a stronger and more effective/transparentsolutionto deal with this issue. Our proposed framework has the purpose to reduce violence against women and girls. We would add recommendations to the existing prevention programs and we would try to make them more effective in dealing with the violence against women and girls. We note here, that if these or any other suggestions by critics are not taken properly into consideration, such inaction constitutes a political act of inability. These inactions by nature are unjustifiable as we have clearly stated in the previous sections of this paper that violence is an unjust act. We have properly analyzed its consequences on women and their lasting effects on their welfare and education. However, these suggestions have to be taken into the proper settings and relevance. In the following sections, we would discuss some of the justifiable actions that governments have to undertake to reduce poverty. As mentioned, any inaction constitutes an act of political inability to work towards great reduction and therefore unjustifiable by nature.

\subsection{Poverty reduction}

Violence against women occurs in all level of social and economic classes. However, women who live in poverty are most likely to be victims of violence. Poverty adversely affects families and it creates the likely environment for violence against women and girls. In 1998 United Nations agencies adopted a general definition for poverty which wasaccepted by majority of people and organizationsas follows(Gordon, 2005):

Fundamentally, poverty is a denial of choices and opportunities, a violation of human dignity. It means lack of basic capacity to participate effectively in society. It means not having enough to feed and cloth a family, not having a school or clinic to go to, not having the land on which to grow one's food or a job to earn one's living, not having access to credit. It means insecurity, powerlessness and exclusion of individuals, 
households and communities. It means susceptibility to violence, and it often implies living on marginal or fragile environments, without access to clean water or sanitation.

(UN Statement, June 1998 - signed by the heads of all UN agencies)

Poverty is a fact of life for millions of people all over the world, despite their ethnicity, age or social status. However, it has a huge impact and creates the premise for violence against women and girls. The reduction of poverty in the poor areas of the world could potentially decrease violence. We believe that the class segregation reduction would provide an opportunity to ally violence against women with poverty reduction efforts aimed at protecting the poorest and most vulnerable women (Abama and Kwaja, 2009). That is, we argue that governments should develop programs to reduce poverty. This could be achieved via well established and proven mechanism such as tax restructuring and proper distribution of public funds. Basically, we arguing that tax restructuring could help eliminate class segregation to some extent. In addition, proper redistribution could provide more effective and efficient use of public funds. These actions could help reduce to a certain level the poverty. These would have an indirect decreasing effect on poverty.

Alice O'Connor paid close attention to the history and the phenomenon of poverty and welfare. Her concept of welfare reform for equating classes could be applied for the purposes of violence reduction. She believed that welfare reform could be (O’ Connor, 2002):

a triumph of politics and ideology over knowledge, ... and a defeat for the policy analysts and ideology over knowledge, that is, and a defeat for the policy analysts who had mustered an enormous amount of scientific data showing that the bill would send millions more children into poverty - very much in the hope of preventing politicians from doing the wrong thing.

We have to note that there is existing solution to reduction of poverty that could be applied to any given case. All the circumstances have to be taken into consideration, in addition to the specific region under the question. "But decent work - the promotion of rights, employment, social protection and dialogue - will always be at the heart of successful policies to get there" (Somavía, 2007).

\subsection{Improvements in education}

We have to note that violence has a huge impact on the mental, physical and emotional consequences not only for the abused one, but also to the children who are around. The implication of violence can harm the children and their future development, productiveness and in their development of an active adult. Many children (boys or girls) often experience problems at school in an early stage. They have harder time to concentrate at their studies; their low self-esteem and even they are regularly missing from school due health problems. In order to prevent the effect of violence of young adults, governments need to formulate a place for universal primary education offered to everyone despite their gender and age. This also may contribute to the reduction of violence against women and girls (Abama and Kwaja, 2009).

"For over a decade, education for girls has been identified as one of the best solutions to reversing the relentless trend of poverty" (Cotton, 2007). "Education for all means that all children, not just the academically gifted or elites, must be given the chance to complete their education in a safe environment"(Cotton, 2007). Education is blessing and no matter of the gender, the age, the culture or religion of a person he or she has the right to it. That is, we argue here that if governments invest in education, these costs could justify reduction of violence. This would not always be the case but it could provide means towards indirect reduction.

\subsection{Reduction of inequality}

This subsection is some interchanging arguments as the previously discussed "poverty reduction" from above. In here, we argue that governments should work and develop better social programs towards reduction of inequality. As we have discussed, "violence against women is one of the most visible outcomes of gender inequality and women's lack of empowerment" (Summary Report of Women Forums, 2008). As conferred, the act of violence can have a shattering effect to the victims self-drive. In addition, these subsequent effects could have a greater impact on the future well-being as well as the perspective of future participation of the individual in the activities of the society. That is, the victims of violence are subjected to fewer opportunities for their future development [(Grown et al, 2005), (Abama and Kwaja, 2009)]. That is, in here we argue that governments should provide more effective and efficient use of public fundsand utilize these funds towards creating more opportunities for women. These actions could help reduce to a certain level the inequality. These would have an indirect decreasing effect on poverty.

We note that there is no "silver bullet" that could have a direct effect on reduction of violence against women and girls. However, governments should do anything in their power (respective of costs) to decrease and eliminate violence from occurring. This could entail the established of more proper redistribution of government funds, 
adjustments in the tax system and improvements in the educational system. These three components would have an indirect effect on reduction of violence as argued in this paper.

\section{Conclusion}

In conclusion, we must be aware that violence against women and girls is happening the same time as we speak. We have the obligation to work towards these goals and to develop policies and design development programs, which will reduce and even eliminate violence. Violence against women and girls simple denies women equality and give men the right to use violence to reduce women's independence and self-confidence even before the law. This must be changed because men and women are humans which life the same life, breath the same air and look the world through the same glasses. Amplified attention must be paid by responsible parties to ensure that proper action is undertaken to mitigate the risks of violence actions against women and girls. As we have previously stated, any inaction by governments towards reduction of violence against women and girls is constitutes an act of political inability to work towards great reduction and therefore unjustifiable by nature.

\section{References}

Abama, E., \& Kwaja, C. (2009). Violence Against Women in Nigeria: How the Millennium Development Goals Address the Challenge. Journal of Pan AfricanStudies, 3 (3).

Baker, L., \& Jaffe, P. (2007). Woman abuse affects our children (A Educator's Guide). [Online] Available: http://www.lfcc.on.ca/Educators_Guide_to_Woman_Abuse.pdf (November, 2011)

Barker, G., Ricardo, C., \& Marcos, N. (2007). Engaging men and boys in changing gender-based inequity in health: Evidence from programme interventions, WHO Geneva. [Online] Available: www.who.int/gender/docu ments/Engaging_men_boys.pdf (November, 2011).

Britannica. (2000). By IncNetLibrary (Definitions).

Convention on the Elimination of All Forms of Discrimination against Women (CEDAW). (1979). [Online] Available: http://www.un.org/womenwatch/daw/cedaw/text/econvention.htm (November, 2011)

Cotton, A. (2007). The Importance of Educating Girls and Women -The Fight Against Poverty in African Rural Communities. [Online] Available: http://www.un.org/wcm/content/site/chronicle/cache/bypass/home/archive/iss ues2007/themdgsareweontrack/theimportanceofeducatinggirlsandwomenthefightagainstpovertyinafricanruralco mmunities?ctnscroll_articleContainerList=1_0\&ctnlistpagination_articleContainerList=true (November, 2011)

Council of Europe. (2006). Campaign to Combat Violence against Women, including Domestic Violence, Fact sheet: Council of Europe. [Online] Available: http://www.coe.int/t/dg2/equality/domesticviolencecampaign/Sou rce/EG-VAW(2006)1_rev_3_En.pdf(November, 2011)

Council of Europe. (2009). Declaration: Making gender equality a reality 119th Session of the Committee of Ministers. [Online] Available: https://wcd.coe.int/ViewDoc.jsp?id=1441675\&Site=CM (November, 2011)

Council of Europe. (2011). Equality between Women and Men. [Online] Available: www.coe.int/T/e/human_righ ts/equality (November, 2011)

Council of Europe (2011). Gender Equality. [Online] Available: http://www.eycb.coe.int/compasito/chapter_5/7. html (November, 2011)

Council of Europe. (2011). Stop Domestic Violence against Women. [Online] Available: www.coe.int/t/dc/campai gn/stopviolence/default_en.asp (November, 2011)

Declaration on the Elimination of Violence against Women. (1993). United Nations (UN). [Online] Available: www.unhchr.ch/huridocda/huridoca.nsf/ (Symbol)/A.RES.48.104.En (November, 2011)

Family Violence Prevention and Services Act. (1984). [Online] Available: http://www.womenshealth.gov/violen ce-against-women/laws-on-violence-against-women/ (November, 2011)

Garcia-Moreno, C., Jansen, A. F. M., Ellsberg, M., Heise, L., \& Watts, C. (2006). Prevalence of intimate partner violence: Findings from the WHO multi-country study on women's health and domestic violence. Lancet, 368, 1260-69. [Online] Available: http://www.who.int/gender/violence/who_multicountry_study/media_corner/Preva lence_intimatepartner_WHOStudy.pdf (November, 2011)

Gordon, D. (2005). Indicators of Poverty \& Hunger. Expert Group Meeting on Youth Development Indicators United Nations Headquarter. [Online] Available: http://www.un.org/esa/socdev/unyin/documents/ydiDavidGo rdon_poverty.pdf(November, 2011)

Grown, C., \& Greeta. R. (2005). Taking Action: achieving gender equality and empowering women.Publisher: the United Nations Development Programme. 
Heise, L., Pitanguy, J., \& Germain, A. (1994). Violence against women: the hidden health burden. [Online] Available: http://www-wds.worldbank.org/external/default/WDSContentServer/WDSP/IB/1999/04/28/0000092 65_3970716144635/Rendered/PDF/multi0page.pdf (November, 2011)

Human Right Act. (1998). [Online] Available:http://www.cepr.org/aboutcepr/policies.htm (November, 2011) Karmen, A. (2007). Crime Victims: An Introduction to Victimology.

Kaukinen, C. (2004). Status Compatibility, Physical Violence, and Emotional Abuse in Intimate Relationships. Journal of Marriage and Family, 66, 452-471.

New York Times. (1997). Survey by the Kenyan Women Rights Awareness Program.

O'Connor, A. (2002). Poverty Knowledge: Social Science, Social Policy, and the Poor in Twentieth-Century U.S. History. Politics and Society in Twentieth-Century America.

Office of UN High Commission on Human Rights. (2007). [Online] Available: http://www2.ohchr.org/english/la w/ (November, 2011) and http://www.womenshealth.gov/violence-against-women/laws-on-violence-against-wo men/ (November, 2011)

Office on Women's Health. (2011). Part of the US Department of Health and Human Services. [Online] Available: http://www.womenshealth.gov/violence-against-women/laws-on-violence-against-women/ (November, 2011)

Open Society Institute. (2008). Summary Report of Women Forums Reclaiming Information Communication Technology to end Violence Aganist Women. [Online] Available: http://www.apc.org/en/system/files/Summary_ report_Women\%20Fourms_Reclaiming\%20ICT\%20to\%20end\%20VAW.pdf (November, 2011)

Rome Statute of the International Criminal Court. (1998). [Online] Available: http://untreaty.un.org/cod/icc/statu te/romefra.htm (November, 2011)

Somavía, J. (2007). Promoting the MDGs: The Role of Employment and Decent Work. [Online] Available: http://www.un.org/wcm/content/site/chronicle/cache/bypass/home/archive/issues2007/themdgsareweontrack/pro motingthemdgstheroleofemploymentanddecentwork?ctnscroll_articleContainerList=1_0\&ctnlistpagination_artic leContainerList=true (November, 2011)

Stokes, R. (2002). Human Resources Consultant, UT Municipal Technical Advisory Service. Testimony given at public hearing on the economic impact of domestic violence.

Thun, E. (2002). Gender Stereotypes in the School. Hírn'k Feminist webportal

UN Commission on the Status of Women. (2000). Press Release, Millions of Women Still Live in Poverty, Executive Director of the UN...”. [Online] Available: http://www.un.org/News/Press/docs/2000/20000228.wom 1178.doc.html (November, 2011)

UN GA Resolution. (1996). The role of the United Nations Development Fund for Women in eliminating violence against women RESOLUTION 50/166 50/166 [on the report of the Third Committee (A/50/630 and Corr.1)] 16 February 1996. [Online] Available: http://www.unhchr.ch/Huridocda/Huridoca.nsf/(Symbol)/A.RES.50.166.En? Opendocument (November, 2011)

UN Trust Fund to End Violence against Women. (2011). [Online] Available: http://www.unwomen.org/how-we -work/un-trust-fund/ (November, 2011)

UN Women. (2010). United Nations Entity for Gender Equality and the Empowerment of Women. [Online] Available: www.un.org/womenwatch/daw/egm/IndicatorsVAW/IndicatorsVAW_EGM_report.pdf (November, 2011)

UNICEF. (2002). Optional Protocol to the Convention on the Rights of the Child on the sale of children, child prostitution and child pornography (General Assembly resolution A/RES/54/263). [Online] Available: http://www2.ohchr.org/english/law/crc-sale.htm (November, 2011)

Vienna Declaration and Program of Action. (1993). [Online] Available: http://www.unhchr.ch/huridocda/huridoca. nsf/(symbol)/a.conf.157.23.en (November, 2011)

Violence Against Women Act. (1994). [Online] Available: http://www.womenshealth.gov/violence-against-wo men/laws-on-violence-against-women/ (November, 2011)

WHO. (2011). Violence against women, intimate partner and sexual violence against women. [Online] Available: http://www.who.int/mediacentre/factsheets/fs239/en/

World Bank. (2011). About us. [Online] Available: http://web.worldbank.org/WBSITE/EXTERNAL/EXTABOU TUS/0,,pagePK:50004410 piPK:36602 theSitePK:29708,00.html (November, 2011) 